\title{
煎茶用品種“はるもえぎ’の育成
}

\author{
宮崎県総合農業試験場茶業支場* \\ 長友博文・水田隆史・佐藤邦彦 \\ 宮崎県西臼杵農業改良普及センター** \\ 吉留浩 \\ 元宮崎県総合農業試験場茶業支場 \\ 古野鶴吉・上野貞一・平川今夫・間曽龍一・安部二生 \\ (平成15年11月26日受理)
}

\section{A New Cultivar 'Harumoegi' for Green Tea}

\author{
Hirofumi Nagatomo, Takashi Mizuta, Kunihiko Sato \\ Tsuruyoshi Furuno, Sadaichi Ueno, Imao Hirakawa, \\ Ryuichi Maso and Tsugio Abe \\ Tea Branch, Miyazaki Prefectural Agricultural Experiment Station \\ Hiroshi Yoshidome \\ Nishiusuki Agricultural Extension Center
}

\section{Summary}

A new cultivar 'Harumoegi' for green tea was bred at the Tea Branch, Miyazaki Prefectural Agricultural Experiment Station and registered as Cha Norin No.51 by the Ministry of Agriculture, Forestry and Fisheries in September, 2003. This cultivar was selected out of seedlings crossed between 'NN27' and 'ME52' in 1981.

The characteristics of the cultivar are as follows;

This cultivar is medium budding, both the flushing and the plucking times of the 1st crop are 2 days later than in 'Yabukita'. The shape of the plant is erect type and the growth is fairly vigorous. The spread of tea bush is narrower than in 'Yabukita'. The color of immature leaves is light green.

It is middle susceptible to tea anthracnose (Colletotrichum theae-sinensis) and resistant to tea gray blight (Pestalotiopsis longiseta). It is fairly resistant both to cold in midwinter and to bark split frost injury in earlywinter. The annual green leaf yield is much the same of 'Yabukita'. Quality of the processed tea is very good because the color is bright green, both aroma and taste are mild. The content of amino acids in the processed tea is high, the content of tannin is low.

Key words: 'Harumoegi', new cultivar, green tea, desease resistance, medium budding

* $\quad$ T889-1301 宮崎県児湯郡川南町大字川南17070

** T882-1101 宮崎県西臼杵郡高千穂町大字三田井字堂山3364-39 


\section{1 緒言}

現在, 全国の茶栽培面積の約 $77 \%$ \%生品種 のやぶきたかが占めており†，この単一品種への栽 培の集中により，摘採作業や防除作業の集中に よる労力不足や病害虫の多発等の弊害が発生し ている。

‘やぶきた’は夏茶の製茶品質がやや劣るため, 宮崎県や鹿児島県等においては, 品質改善対策 として寒冷紗の直接被覆が広く行われている。 また, ‘やぶきた’は輪斑病や炭瘨病に弱い。この ため, 生産者からは夏茶品質の良い耐病性品種 が求められている。

宮崎県総合農業試験場茶業支場 (農林水産省 茶育種指定試験地)では，輪斑病抵抗性に優れ， 高品質で夏茶においても色沢が優れる中生の煎 茶用品種茶農林51号“はるもえぎを育成したので, その来歴, 育成経過並びに試験成績の概要を報 告する。

なお，本品種の育成に際し，栄養系適応性検 定試験 (以下, 系適試験という), 特性検定試験 及び県単独事業に上る地域適応性検定試験等に ご協力いただいた関係場所を以下に記し, 関係 者各位に深甚の謝意を表する。

\section{農林水産省指定系適試験場所}

茨城県農業総合センター山間地帯特産指導所

三重県科学技術振興センター茶業センター

(現農業研究部茶業研究室)

京都府立茶業研究所

高知県農業技術センター茶業試験場

熊本県農業研究センター茶業研究所

農林水産省指定特性検定試験場所
静岡県茶業試験場（もち病抵抗性）

鹿児島県茶業試験場（裂傷型凍害抵抗性） 県単独事業による地域適応性検定試験場所

埼玉県茶業試験場

(現農林総合研究センター茶業特産研究所) 岐皁県農業技術研究所池田試験地 静岡県茶業試験場 濼賀県茶業指導所

（現農業総合センター茶業指導所） 奈良県農業試験場茶業分場

（現農業技術センター茶業振興センター）

岡山県農業試験場北部支場

香川県農業試験場満濃分場

福岡県農業総合試験場八女分場

佐賀県茶業試験場

大分県農業技術センター茶業特産部

鹿児島県茶業試験場

\section{2 来歴及び䏍成経過}

“はるもえぎの育成期間は, 交配から農林登録 まで22年であり，育成には 9 名の関係者が携わっ ている。

本品種は，1981年に当支場におるいて，樹勢の 強い“茶本 $F_{1} N N 27 ’ を$ 種子親, 高品質で輪斑病に 強い'ME52’を花粉親として交配を行い, 得られ た4,983個体の中から選抜して育成したものであ る(図 1 )。

1982年 9 月に採種し, 同年12月にこのうち 4,968個体を甬場に播種した。1983年から1985 年まで 3 年間個体選抜試験を行い, 葉色及ひ耐 病性等の優れた34個体について1985年 6 月に挿 し木を行った。1986年 5 月に定植し，1990年ま での 5 年間'Mi86-39’の系統名で栄責系比較試

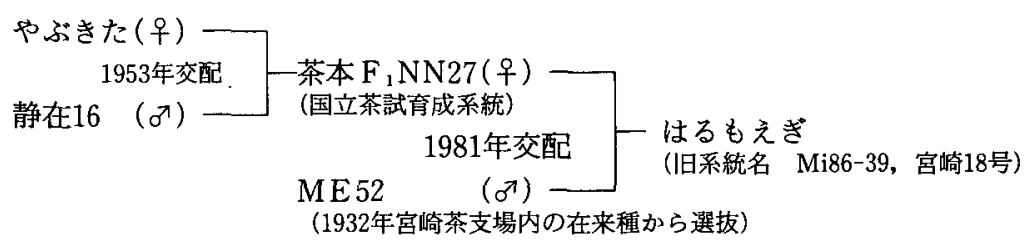

図 1 ‘はるもえぎの青成系統図

$†$ 社団法人日本茶業中央会: 平成 15 年度版茶関係資料, $\mathrm{p} 25$ 
(茶研報96：15～26，2003）

表 1 ‘はるもえぎの新品種としての有望度

\begin{tabular}{|c|c|c|c|c|c|c|c|c|c|}
\hline 場 & 所 & 有 & 望 & 度 & 場 & 所 & 有 & 望 & 度 \\
\hline 茨 & 城 & & 3 & & 岡 & 山 & & 2 & \\
\hline 三 & 重 & & 3 & & 香 & 川 & & 3 & \\
\hline 京 & 都 & & 3 & & 福 & 岡 & & 3 & \\
\hline 高 & 知 & & 2 & & 佐 & 賀 & & 2 & \\
\hline 熊 & 本 & & 4 & & 大 & 分 & & 2 & \\
\hline 岐 & 阜 & & 4 & & 鹿 児 & 島 & & 4 & \\
\hline 奈 & 良 & & 3 & & & & & & \\
\hline
\end{tabular}

a 有望度は系適試験最終年度の評価

評価：1(見込みなし)〜 5 (有望)

験を実施し，生育及び品質特性を調査した。

1991年から“宮崎18号”の系統名で茨城, 三重, 京都, 高知, 熊本の各府県で系適試験 (第 7 群) を, 静岡県 (もち病), 鹿児島県 (裂傷型凍害) で特性検定試験及び県単試験を開始した。また, 1992年からは新たに10県（宮崎県を含む）の公 立場所でも県単試験を開始した。1999年までの 系適試験の結果では，最終年度におりる各府県 の有望度は表 1 のとおりで,やや有望とした県 は13府県中 3 県と少なかった。しかし、南九州 では品質、収量に対する評価が高く、品種化の 要望が出された。これを受けて，2003年 1 月に
開催された「茶新品種候補検討委員会」及び同 年 3 月の「平成 14 年度野菜・茶業試験研究推進 会議」での審議を経て, 農林水産大臣に新品種 命名登録申請を行った。

その結果, 2003 年 9 月 5 日に茶農林 51 号ははる もえぎとして農林登録された。

\section{3 特 性の概 要}

\section{1 形態的特性}

樹姿は直立型で,樹勢はやや強,株張りはやや 小である。枝条の節間長及び太さは‘やぶきた’と 同程度である。着葉角度はやや鈍角である(表2)。

\section{表 2 育成地における一般特性及び生育特性}

\begin{tabular}{|c|c|c|c|c|c|c|c|}
\hline \multirow[b]{2}{*}{ 品 種 名 } & \multirow[b]{2}{*}{ 樹 } & \multirow[b]{2}{*}{ 樹 } & \multirow[b]{2}{*}{ 株 張 り } & \multirow[b]{2}{*}{$\begin{array}{l}\text { 葉層の } \\
\text { 厚 さ }\end{array}$} & \multicolumn{2}{|c|}{ 枝条の形質 ${ }^{a}$} & \multirow[b]{2}{*}{ 着葉角度 } \\
\hline & & & & & $\begin{array}{c}\text { 節間長 } \\
(\mathrm{cm})\end{array}$ & $\begin{array}{c}\text { 太d } \\
(\mathrm{mm})\end{array}$ & \\
\hline はるもえぎ & 直立 & やや強 & やや小 & 中 & 2.9 & 2.1 & やや鈍角 \\
\hline やぶきた & やや直立 & やや強 & 中 & 中 & 2.8 & 2.2 & やや鋭角 \\
\hline かなやみどり & 開張 & 中 & 大 & やや厚 & 2.9 & 2.0 & 中 \\
\hline
\end{tabular}

a 枝条の形質は, 一番茶硬化枝条の中央部を測定。2003年調査

\section{表 3 育成地における新葉の形質 ${ }^{\mathrm{a}}$}

\begin{tabular}{|c|c|c|c|c|c|c|c|c|c|c|}
\hline 品 種 名 & 形 状 & $\begin{array}{l}\text { 葉長 } \\
(\mathrm{cm})\end{array}$ & $\begin{array}{l}\text { 葉幅 } \\
(\mathrm{cm})\end{array}$ & $\begin{array}{l}\text { 葉形 } \\
\text { 指数 }\end{array}$ & $\begin{array}{c}\text { 葉面積 } \\
\left(\mathrm{cm}^{2}\right)\end{array}$ & $\begin{array}{l}\begin{array}{l}\text { 葉厚 } \\
(\mathrm{mm})\end{array} \\
\end{array}$ & 葉 色 ${ }^{\mathrm{c}}$ & 光沢 & & $\begin{array}{l}\text { 毛茸の } \\
\text { 多 少 }\end{array}$ \\
\hline るもえぎ & だ & 4.60 & 2.17 & 2.12 & 6.96 & 0.180 & & & & やや多 \\
\hline 了ぶきた & 長だ円 & 4.78 & 1.80 & 2.66 & 6.01 & 0.148 & 緑 $(75 \mathrm{CYh}$ & & 中 & やや多 \\
\hline ふなやみどり & ややだ円 & 4.55 & 1.96 & 2.32 & 6.24 & 0.197 & 濃緑(7.5GY4/5.5) & やや多 & 中 & pや多 \\
\hline
\end{tabular}

a 調查方法は「チャ育種要綱」による。2003年調査

b 葉形指数 $=$ 葉長 $/$ 葉幅

c（）内は，標準葉色帖による。 
新葉及び成葉の形状はともにだ円形で，大き さは中，葉厚も中である。葉色は新葉，成葉と も淡緑で, 光沢はやや多である。新葉の葉襄に は全面に毛菆が密生している（表 3, 表 4)。

\section{2 萌芽期及び摘採期}

育成地における一番茶の萌芽期は 4 月 5 日で， ‘やぶきた’より 2 日遅く，摘採期は‘やぶきた’よ り 4 日程度遅い 5 月 1 日であった（表 5 ）。

系適試験においては, 萌芽期は全場所平均で ‘やぶきた’より 1 日遅く，摘採期は 3 日遅かった。 普及が見込まれる宮崎県及び鹿児島県において は, ‘やぶきた’と‘かなやみどり’間で摘採可能 な中生品種として利用できる（表 6 )。

\section{3 生育及び収量}

系適試験における育苗成績では, 苗の生存率 は平均 $85 \%$ ，生育が 5 段階評価で3.8と評価さ れ，ややぶきた'(同 $85 \% ， 3.8$ ) と同程度である。
定植後の活着率の平均は $86 \%$ で, 場所によって は‘やぶきた’(同93\%)に比べやや劣る場合が見 られた（表 7 )。

育成地での系適試験における生葉収量は，5 〜 年生の平均で, 一番茶が $418 \mathrm{~kg}$ ('やぶきた' 比 $91 \%$ )，二番茶は $479 \mathrm{~kg}$ (同110\%)である(表 8)。一番茶の摘芽調查（表 9) において, ‘ ぶきた’に比べ単位面積当たりの摘芽数がやや多 く，百芽重もかずかに大きいにもかかわらず， 一番茶収量がやぶきた’よりやや低かったのは， 本品種の樹姿が直立型であること及び単条植え の試験畕場であることにより,株張りが小さかっ たことが原因と考えられる。

系適試験の結果でも, 約半数の場所がやぶき た’より生葉収量が低いとしている。しかし，摘 採面当たり収量は, 約 8 割の場所でやぶきた’以 上となって扔り，株張りを確保することで安定 した収量を得ることが可能であると考えられる (表6)。

\section{表 4 育成地における成葉の形質 ${ }^{\mathrm{a}}$}

\begin{tabular}{|c|c|c|c|c|c|c|c|c|c|c|c|}
\hline 品 種 名 & 形 & $\begin{array}{l}\text { 葉長 } \\
(\mathrm{cm})\end{array}$ & $\begin{array}{l}\text { 葉幅 } \\
(\mathrm{cm})\end{array}$ & $\begin{array}{l}\text { 潹形 } \\
\text { 指数 }{ }^{b}\end{array}$ & $\begin{array}{c}\text { 葉面積 } \\
\left(\mathrm{cm}^{2}\right)\end{array}$ & $\begin{array}{l}\text { 葉厚 } \\
(\mathrm{mm}) \\
\end{array}$ & 色 $^{c}$ & 光沢 & $\begin{array}{l}\text { 葉面の葉 } \\
\text { しわの }\end{array}$ & 内折度 & \\
\hline はるもえぎ & だ円 & 6.70 & 3.10 & 2.16 & 14.5 & 0.243 & 淡緑(7.5GY4/4) & や队多 & やや少 & やや小 & やや小 \\
\hline やぶきた & 舆だ円 & 7.63 & 2.97 & 2.57 & 15.9 & 0.278 & 緑 (7.5GY3.5/4.5) & やや多 & 中 & 中 & 中 \\
\hline かなやみどり & 長 & 6.92 & 2.78 & 2.49 & 13.5 & 0.269 & 濃緑(7.5GY3.5/3) & 多 & やや少 & やや小 & 中 \\
\hline
\end{tabular}

a 調查方法は「チャ育種要綱」による。2003年調査

b 葉形指数 $=$ 葉長 /葉幅

c（）内は，標準葉色帖による。

\section{表 5 育成地における萌芽期及び摘採期}

\begin{tabular}{|c|c|c|c|c|c|c|c|c|c|c|c|c|c|c|c|}
\hline & \multirow{2}{*}{ 品 種 名 } & \multicolumn{6}{|c|}{ 栄盖系比較試験（月日） } & \multicolumn{6}{|c|}{ 系適試験（月日） } & \multirow{2}{*}{ 全平均 } & \multirow{2}{*}{$\begin{array}{c}\text { 比較 }^{\mathrm{a}} \\
\text { (日) }\end{array}$} \\
\hline & & 1986年 & 1987年 & 1988年 & 1989年 & 1990年 & 平均 & 1995年 & 1996年 & 1997年 & 1998年 & 1999年 & 平均 & & \\
\hline & はるもえぎ & 4. 6 & 4.7 & 4.10 & 4. 9 & 4. 1 & 4. 6 & 4. 7 & 4. 6 & 4. 1 & 4. 4 & 4. 6 & 4. 4 & 4. 5 & +2 \\
\hline \multirow[t]{3}{*}{ 萌芽期 } & やぶきた & 4. 5 & 4. 6 & 4. 6 & 4. 6 & 3.29 & 4. 4 & 4. 7 & 4. 5 & 3.31 & 4. 1 & 4. 2 & 4. 3 & 4. 3 & \pm 0 \\
\hline & かなやみどり & 4.10 & 4.11 & 4.11 & 4. 9 & 4. 1 & 4. 8 & 4.10 & 4. 9 & 4. 3 & 4.5 & 4. 6 & 4. 6 & 4. 7 & +4 \\
\hline & はるもえぎ & - & - & 5. 6 & 5.4 & 5.3 & 5. 4 & - & - & 5.1 & 4.25 & 4.30 & 4.28 & 5. 1 & +4 \\
\hline \multirow[t]{2}{*}{ 摘採期 } & やぶきた & - & - & 5. 4 & 4.28 & 4.28 & 4.30 & - & - & 4.30 & 4.20 & 4.26 & 4.25 & 4.27 & \pm 0 \\
\hline & かなやみどり & - & - & 5. 6 & 5. 3 & 5. 2 & 5. 3 & - & - & 5. 1 & 4.24 & 5. 2 & 4.29 & 5. 1 & +4 \\
\hline
\end{tabular}

$\mathrm{a}$ ‘やぶきた’より早いものを一 $\mathrm{n}$ 日, 遅いものを+ $\mathrm{n}$ 日で表示 
(茶研報96：15～26, 2003)

表 6 系適試験における萌芽期, 摘採期及び収量

\begin{tabular}{|c|c|c|c|c|c|c|c|c|c|}
\hline \multirow[b]{2}{*}{ 場 } & \multirow[b]{2}{*}{ 品 種 名 } & \multicolumn{2}{|c|}{ 萌芽期 } & \multicolumn{2}{|c|}{ 摘採期 ${ }^{\mathrm{a}}$} & \multicolumn{2}{|c|}{ 生葉收量 ${ }^{\mathrm{c}}$} & \multicolumn{2}{|c|}{ 摘採面当たり収量 } \\
\hline & & 月日 & $\begin{array}{l}\text { 比較 }^{\mathrm{b}} \\
\text { (日) }\end{array}$ & 月日 & $\begin{array}{l}\text { 比較 }^{b} \\
\text { (日) }\end{array}$ & $\begin{array}{l}\text { 一番茶e } \\
\text { (指数) }\end{array}$ & $\begin{array}{l}\text { 二番茶 } \\
\text { (指数) }\end{array}$ & $\begin{array}{l}\text { 番茶 } \\
\text { (指数) }\end{array}$ & $\begin{array}{c}\text { 二番茶 } \\
\text { (指数) }\end{array}$ \\
\hline \multirow{3}{*}{ 茨 } & はるもえぎ & $4.17^{1}$ & +0 & $5.27^{\mathrm{h}}$ & +5 & $115^{\mathrm{k}}$ & $119^{\mathrm{k}}$ & $121^{\mathrm{m}}$ & $129^{\mathrm{m}}$ \\
\hline & やぶきた & 4.17 & \pm 0 & 5.22 & \pm 0 & 100 & 100 & 100 & 100 \\
\hline & かなやみどり & 4.18 & +1 & 5.26 & +5 & 122 & 104 & 105 & 93 \\
\hline \multirow{3}{*}{$\equiv$} & はるもえぎ & $4.10^{8}$ & +1 & $4.30^{\mathrm{g}}$ & +1 & $75^{1}$ & $81^{1}$ & $88^{\mathrm{m}}$ & $90^{\mathrm{m}}$ \\
\hline & や゙ぶきた & 4. 9 & \pm 0 & 4.30 & \pm 0 & 100 & 100 & 100 & 100 \\
\hline & かなやみどり & 4.11 & +2 & 5. 4 & +4 & 127 & 92 & 115 & 94 \\
\hline \multirow{3}{*}{ 京 } & はるもえき & 4. $9^{f}$ & +3 & 5. $7^{\mathrm{h}}$ & +1 & $146^{\mathrm{k}}$ & $125^{\circ}$ & $134^{\bar{k}}$ & $109^{\circ}$ \\
\hline & やぶきた & 4. 6 & \pm 0 & 5. 6 & \pm 0 & 100 & 100 & 100 & 100 \\
\hline & かなやみどり & 4.12 & +6 & 5. 8 & +2 & 63 & - & 71 & - \\
\hline \multirow{3}{*}{ 高 } & はるもえき & $4.2^{\mathrm{h}}$ & +2 & $4.30^{\mathrm{h}}$ & +2 & $106^{\mathrm{k}}$ & $94^{\mathrm{k}}$ & $111^{\mathrm{k}}$ & $100^{\mathrm{k}}$ \\
\hline & やぶきた & 3.31 & \pm 0 & 4.28 & \pm 0 & 100 & 100 & 100 & 100 \\
\hline & かなやみどり & 4. 4 & +4 & 5. 1 & +2 & 131 & 131 & 114 & 125 \\
\hline \multirow[b]{2}{*}{ 熊 } & はるもえぎ & 4. $2^{\mathrm{h}}$ & +2 & $5.2^{\mathrm{g}}$ & +2 & $153^{\mathrm{m}}$ & - & $108^{5}$ & - \\
\hline & やぶきた & 4. 1 & \pm 0 & 4.30 & \pm 0 & 100 & - & 100 & - \\
\hline & かなやみどり & 4. 3 & +2 & 5. 2 & +2 & 97 & - & 87 & - \\
\hline 埼 & 汇るもえぎ & $4.16^{1}$ & \pm 0 & $5.15^{\mathrm{j}}$ & +3 & - & - & - & - \\
\hline$\pi$ & やぶきた & 4.16 & \pm 0 & 5.12 & \pm 0 & - & - & - & 二 \\
\hline 岐 & はるもえぎ & $3.26^{j}$ & -1 & - & - & - & - & - & - \\
\hline 报 & やぶきた & 3.27 & \pm 0 & - & - & - & - & - & - \\
\hline & はるもえき & 4. $5^{8}$ & +2 & $5.2^{8}$ & \pm 0 & $89^{n}$ & $120^{\mathrm{n}}$ & $99^{n}$ & $132^{n}$ \\
\hline 岡 & やぶきた & 4. 3 & \pm 0 & 5.1 & \pm 0 & 100 & 100 & 100 & 100 \\
\hline & かなやみどり & 4. 6 & +3 & 5.2 & +1 & 103 & 123 & 87 & 101 \\
\hline & はるもえぎ & $4.12^{\mathrm{j}}$ & \pm 0 & - & - & - & - & - & - \\
\hline 滋 & やぶきた & 4.12 & \pm 0 & - & - & - & - & - & - \\
\hline & かなやみどり & 4.15 & +3 & - & - & - & - & - & - \\
\hline & はるもえぎ & $4.20^{\mathrm{J}}$ & -1 & $5.25^{j}$ & +1 & $58^{\circ}$ & $55^{\circ}$ & $101^{\circ}$ & $95^{\circ}$ \\
\hline 奈 & やぶきた & 4.21 & \pm 0 & 5.24 & \pm 0 & 100 & 100 & 100 & 100 \\
\hline & かなやみどり & 4.22 & +1 & 5.19 & -5 & 59 & 92 & 51 & 79 \\
\hline & はるもえぎ & $4.15^{1}$ & +1 & $5.17^{\mathrm{j}}$ & +7 & - & - & - & - \\
\hline 山 & やぶきた & 4.14 & \pm 0 & 5.10 & \pm 0 & - & - & - & - \\
\hline & かなやみどり & 4.17 & +3 & 5.17 & +7 & - & - & - & - \\
\hline & はるもえぎ & $4.11^{\mathrm{h}}$ & +3 & $5.8^{h}$ & +3 & $96^{p}$ & $90^{\mathrm{n}}$ & $109^{t}$ & $101^{t}$ \\
\hline 川 & やぶきた & 4.8 & \pm 0 & 5. 5 & \pm 0 & 100 & 100 & 100 & 100 \\
\hline & かなやみどり & 4.11 & +3 & 5.7 & +2 & 92 & 95 & 86 & 76 \\
\hline & はるもえぎ & 4. $6^{\mathrm{h}}$ & +3 & $5.7^{\mathrm{h}}$ & +2 & $92^{9}$ & $77^{\mathrm{r}}$ & $101^{r}$ & $100^{\mathrm{r}}$ \\
\hline 岡 & やぶきた & 4. 4 & \pm 0 & 5.5 & \pm 0 & 100 & 100 & 100 & 100 \\
\hline & かなやみどり & 4. 7 & +4 & 5.7 & +2 & 113 & 99 & 83 & 92 \\
\hline & はるもえぎ & 4. $3^{g}$ & +1 & $5.2^{g}$ & +5 & $83^{r}$ & $84^{r}$ & $152^{n}$ & $106^{t}$ \\
\hline 佐 & やぶきた & 4. 2 & \pm 0 & 4.27 & \pm 0 & 100 & 100 & 100 & 100 \\
\hline & かなやみどり & 4. 8 & +7 & 5.2 & +5 & 72 & 80 & 110 & 79 \\
\hline & はるもえぎ & $4.11^{8}$ & +5 & $5.15^{8}$ & +8 & $131^{\mathrm{n}}$ & $114^{\mathrm{n}}$ & $159^{\mathrm{r}}$ & $133^{\mathrm{r}}$ \\
\hline 大 & やぶきた & 4. 6 & \pm 0 & 5.7 & \pm 0 & 100 & 100 & 100 & 100 \\
\hline & かなやみどり & 4. 9 & +3 & 5.11 & +4 & 131 & 104 & 140 & 110 \\
\hline & はるもえぎ & 4. $4^{f}$ & +2 & $4.28^{g}$ & +3 & $91^{1}$ & $110^{1}$ & $97^{1}$ & $122^{1}$ \\
\hline 崎 & やぶきた & 4. 3 & \pm 0 & 4.25 & \pm 0 & 100 & 100 & 100 & 100 \\
\hline & かなやみどり & 4. 6 & +4 & 4.29 & +4 & 136 & 140 & 113 & 118 \\
\hline & はるもえぎ & $4.3^{8}$ & +1 & $4.27^{8}$ & +1 & $156^{\mathrm{m}}$ & $100^{\prime}$ & - & - \\
\hline 鹿児島 & やぶきた & 4. 2 & \pm 0 & 4.26 & \pm 0 & 100 & 100 & - & - \\
\hline & かなやみどり & 4. 6 & +4 & 4.28 & +2 & 83 & 80 & - & - \\
\hline & はるもえぎ & 4.8 & +1 & 5. 8 & $+\overline{3}$ & 100 & 98 & 114 & 111 \\
\hline 均 & やぶきた & 4. 7 & \pm 0 & 5. 5 & \pm 0 & 100 & 100 & 100 & 100 \\
\hline & かなやみどり & 4.10 & +3 & 5.7 & +2 & 104 & 108 & 97 & 100 \\
\hline
\end{tabular}

$\mathrm{a}$ データは, $\mathrm{f} 5$ 力年の平均, $\mathrm{g} 3$ 力年の平均, $\mathrm{h} 4$ 力年の平均, $\mathrm{i} 2$ 力年の平均, $\mathrm{j} 1$ 年

b ‘やぶきた’より早いものを一正，遅いものを十n日で表示。なお，四捨五入の関係で月日の差と一致しない 場合加ある

c 生藮収量は10a 当たり収量て, ‘やぶき’を100としたときの值

$\mathrm{d}$ 摘採面当たり収量は, 1 晆収量 $(\mathrm{g})$ \%摘採面積 $\left(\mathrm{m}^{2}\right)$ でやぶさだを100としたときの值

$\mathrm{e}$ 学—多は, $\mathrm{k}$ は $4 \sim 7$ 年生の平均, 1 は $5 \sim 7$ 年生の平均, $\mathrm{m}$ は $6 \sim 7$ 年生の平均, $\mathrm{n}$ は $4 \sim 6$ 年生の平均, $\mathrm{o}$ は 7 年生, $\mathrm{p}$ は $3 \sim 6$ 年生の平均, $\mathrm{q}$ は $3,4,6$ 年生の平均, $\mathrm{r}$ は 6 年生, $\mathrm{s}$ は 5 年生, $\mathrm{t}$ は 5 〜 6 年生の平均 
煎茶用品種“はるもえぎ’の育成

表 7 系適試験における䏍苗成繢及び生育

\begin{tabular}{|c|c|c|c|c|c|c|c|c|c|c|}
\hline \multirow[b]{2}{*}{ 場 所 } & \multirow[b]{2}{*}{ 品種名 } & \multicolumn{2}{|c|}{ 育苗成績 } & \multirow{2}{*}{$\begin{array}{c}1 \text { 年生 } \\
\text { 活着率 } \\
(\%)\end{array}$} & \multicolumn{4}{|c|}{ 定植 2 年目 } & \multicolumn{2}{|c|}{ 定植 6 年目 } \\
\hline & & $\begin{array}{c}\text { 生存率 } \\
(\%)\end{array}$ & $\begin{array}{l}\text { 生育の } \\
\text { 良否 }\end{array}$ & & $\begin{array}{l}\text { 樹高 } \\
(\mathrm{cm})\end{array}$ & $\begin{array}{c}\text { 株張り } \\
(\mathrm{cm})\end{array}$ & $\begin{array}{l}\text { 株張り } \\
\text { 指数 }\end{array}$ & $\begin{array}{l}\text { 生育の } \\
\text { 良否 }\end{array}$ & $\begin{array}{c}\text { 株張 り } \\
(\mathrm{cm})\end{array}$ & $\begin{array}{l}\text { 生育の } \\
\text { 良否a }\end{array}$ \\
\hline \multirow{3}{*}{ 茨 城 } & はるもえぎ & 100 & 3 & 100 & 51 & 37 & 0.73 & 3 & 101 & 5 \\
\hline & やぶきた & 98 & 3 & 100 & 46 & 44 & 0.96 & 3 & 102 & 3 \\
\hline & かなやみどり & 99 & 3 & 100 & 48 & 55 & 1.15 & 3 & 108 & 3 \\
\hline \multirow{3}{*}{ 三 重 } & はるもえぎ & 73 & 3 & 100 & 32 & 24 & 0.76 & 2 & 75 & 4 \\
\hline & やぶきた & 78 & 4 & 100 & 48 & 25 & 0.51 & 4 & 83 & 3 \\
\hline & かなやみどり & 89 & 5 & 100 & 33 & 23 & 0.68 & 2 & 90 & 2 \\
\hline \multirow{3}{*}{ 京 都 } & はるもえぎ & 100 & 4 & 97 & 78 & 44 & 0.56 & 4 & - & 3 \\
\hline & やぶきた & 96 & 4 & 100 & 86 & 55 & 0.64 & 4 & - & 2 \\
\hline & かなやみどり & 87 & 3 & 96 & 74 & 64 & 0.86 & 4 & - & 1 \\
\hline \multirow{3}{*}{ 高 知 } & はるもえぎ & 28 & 4 & 100 & 100 & 49 & 0.49 & 4 & 112 & 4 \\
\hline & やぶきた & 45 & 4 & 100 & 105 & 66 & 0.63 & 4 & 119 & 3 \\
\hline & かなやみどり & 63 & 4 & 100 & 102 & 72 & 0.71 & 3 & 140 & 3 \\
\hline \multirow{3}{*}{ 熊 本 } & はるもえぎ & 96 & 3 & 80 & 51 & 30 & 0.59 & 3 & 96 & 3 \\
\hline & やぶきた & 74 & 3 & 100 & 64 & 42 & 0.66 & 5 & 111 & 4 \\
\hline & かなやみどり & 94 & 3 & 94 & 49 & 44 & 0.90 & 4 & 123 & 4 \\
\hline \multirow{3}{*}{ 埼 玉 } & はるもえぎ & 76 & 2.5 & 78 & 50 & 30 & 0.60 & 1 & - & - \\
\hline & やぶきた & 98 & 3 & 98 & 54 & 52 & 0.96 & 3 & - & - \\
\hline & かなやみどり & 88 & 2.5 & - & - & - & - & - & - & - \\
\hline \multirow{2}{*}{ 岐 阜 } & はるもえぎ & - & - & 100 & 92 & 40 & 0.43 & 4 & - & - \\
\hline & やぶきた & - & - & 98 & 109 & 55 & 0.50 & 4 & - & - \\
\hline \multirow{3}{*}{ 静 岡 } & はるもえぎ & - & - & - & 113 & 66 & 0.58 & - & 126 & 3 \\
\hline & やぶきた & - & - & - & 134 & 95 & 0.71 & - & 149 & 1 \\
\hline & かなやみどり & - & - & - & 113 & 98 & 0.87 & - & 154 & 2 \\
\hline \multirow{3}{*}{ 聯 賀 } & はるもえぎ & 81 & 4 & 80 & 47 & - & - & 3 & - & - \\
\hline & やぶきた & 97 & 5 & 93 & 50 & - & - & 5 & - & - \\
\hline & かなやみどり & 90 & 4 & 87 & 39 & - & - & 4 & - & - \\
\hline \multirow{3}{*}{ 奈 良 } & はるもえぎ & 96 & 5 & 100 & 47 & 22 & 0.47 & 3 & 57 & 3 \\
\hline & やぶきた & 96 & 4.5 & 100 & 48 & 30 & 0.63 & 3 & 83 & 3 \\
\hline & かなやみどり & 93 & 3.5 & 100 & 35 & 28 & 0.80 & 2.5 & 86 & 4 \\
\hline & はるもえぎ & 92 & 5 & 68 & 80 & 32 & 0.40 & 4 & 85 & 2 \\
\hline 岡 山 & やぶきた & 96 & 5 & 78 & 77 & 36 & 0.47 & 5 & 103 & 4 \\
\hline & かなやみどり & 86 & 5 & 30 & 52 & 37 & 0.71 & 4 & 98 & 3 \\
\hline & はるもえぎ & 73 & 3 & 98 & 126 & 63 & 0.50 & 4 & 111 & - \\
\hline 香 川 & やぶきた & 68 & 3 & 94 & 134 & 82 & 0.61 & 4.5 & 108 & - \\
\hline & かなやみどり & 56 & 3 & 100 & 133 & 87 & 0.65 & 4 & 108 & - \\
\hline & はるもえぎ & - & - & - & 90 & 55 & 0.61 & 3.5 & 105 & - \\
\hline 福 岡 & やぶきた & - & - & - & 124 & 88 & 0.71 & 5 & 125 & - \\
\hline & かなやみどり & - & - & - & 100 & 114 & 1.14 & 5 & 133 & - \\
\hline & はるもえぎ & 90 & 5 & 67 & 72 & 40 & 0.56 & 2 & 98 & - \\
\hline 佐 賀 & やぶきた & 88 & 5 & 83 & 99 & 66 & 0.67 & 3 & 137 & - \\
\hline & かなやみどり & 78 & 4 & 60 & 70 & 63 & 0.90 & 2 & 150 & - \\
\hline & はるもえぎ & 90 & 5 & 83 & 47 & 25 & 0.53 & 3 & 145 & - \\
\hline 大 分 & やぶきた & 93 & 3 & 90 & 46 & 32 & 0.70 & 3 & 150 & - \\
\hline & かなやみどり & 90 & 4 & 97 & 54 & 44 & 0.81 & 5 & 163 & - \\
\hline & はるもえぎ & 90 & 3 & 90 & 86 & 39 & 0.46 & 4.5 & 119 & - \\
\hline 宮 崎 & やぶきた & 65 & 3 & 92 & 85 & 45 & 0.53 & 2.5 & 127 & - \\
\hline & かなやみどり & 75 & 2 & 98 & 96 & 78 & 0.82 & 5 & 151 & - \\
\hline & はるもえぎ & 98 & 3.5 & 56 & 46 & 22 & $0 . \overline{49}$ & 2 & 139 & - \\
\hline 鹿児島 & やぶさた & 96 & 3 & 76 & 43 & 26 & 0.62 & 2.5 & 145 & - \\
\hline & かなやどり & 100 & 5 & 90 & 63 & 44 & 0.70 & 4.5 & 145 & - \\
\hline & はるもえぎ & 85 & 3.8 & 86 & 71 & $3 \overline{9}$ & 0.55 & 3.1 & 105 & 3.3 \\
\hline 平 均 & やぶきた & 85 & 3.8 & 93 & 80 & 52 & 0.65 & 3.8 & 119 & 3.6 \\
\hline & かなやみどり & 85 & 3.6 & 89 & 71 & 61 & 0.86 & 3.7 & 127 & 2.8 \\
\hline
\end{tabular}

$\mathrm{a}$ 生育の良否：1 (劣)～5（良）

b 株張り指数 $=$ 株張り/樹高 


\section{4 耐寒性}

育成地における厳寒期の成葉の赤枯れ発生程 度は‘やぶきた’と同程度で, 抵抗性はやや強と考 えられる(表10)。寒さの厳しい茨城県や埼玉県 でも，‘ぶ゙きた’並の評価がされており(表11)， 暖地及び温暖地であれば栽培に支障はないと考

\section{えられる。}

初冬及び早春に発生する裂傷型凍害について 切り枝の低温処理による検定を古野1の方法で 行った。なお，評価基準については古野らがそ の後改訂した基準礼によった。

この結果, 秋芽の生育停止期がやぶきた’より

表 8 育成地の系適試験における生葉収量

\begin{tabular}{|c|c|c|c|c|c|c|c|c|c|c|}
\hline \multirow{2}{*}{ 品 種 名 } & \multicolumn{5}{|c|}{ 一番茶 $(\mathrm{kg} / 10 \mathrm{a})$} & \multicolumn{5}{|c|}{ 二番茶 $(\mathrm{kg} / 10 \mathrm{a})$} \\
\hline & 5 年生 & 6 年生 & 7 年生 & 平均 & 指数 $\mathrm{a}^{\mathrm{a}}$ & 5 年生 & 6 年生 & 7 年生 & 平均 & 指数 ${ }^{\mathrm{a}}$ \\
\hline はるもえぎ & 359 & 338 & 556 & 418 & 91 & 376 & 470 & 589 & 479 & 110 \\
\hline やぶきた & 478 & 372 & 524 & 458 & 100 & 301 & 462 & 547 & 437 & 100 \\
\hline かなやみどり & 423 & 539 & 901 & 621 & 136 & 464 & 694 & 679 & 612 & 140 \\
\hline
\end{tabular}

a ‘やぶきた’を100としたときの值

表 9 育成地における一番茶摘採期の摘芽の形質

\begin{tabular}{lccccc}
\hline 品 種 名 & $\begin{array}{c}\text { 摘芽数 } \\
\left(\text { (本 } / \mathrm{m}^{2}\right)\end{array}$ & $\begin{array}{c}\text { 摘芽長 } \\
(\mathrm{cm})\end{array}$ & $\begin{array}{c}\text { 開葉数 } \\
(\text { 枚 })\end{array}$ & $\begin{array}{c}\text { 百芽重 } \\
(\mathrm{g})\end{array}$ & $\begin{array}{c}\text { 出開き度 } \\
(\%)\end{array}$ \\
\hline はるもえぎ & 2,074 & 9.6 & 3.9 & 59.5 & 42.3 \\
やぶきた & 1,867 & 8.4 & 3.7 & 58.4 & 72.1 \\
かなやみどり & 2,404 & 9.0 & 3.6 & 58.2 & 60.8 \\
\hline
\end{tabular}

a $1997 \sim 1999$ 年の平均値

\section{表10 䏍成地における赤枯れ抵抗性 ${ }^{\mathrm{a}}$}

\begin{tabular}{|c|c|c|c|c|c|c|c|c|c|c|}
\hline 品 種 名 & 1988年 & 1989年 & 1990年 & 1995年 & 1996年 & 1997年 & 1998年 & 1999年 & 平均 & 評 価 \\
\hline はるもえぎ & 1.0 & 2.7 & 1.7 & 1.7 & 2.0 & 1.7 & 2.0 & 2.0 & 1.9 & やや強 \\
\hline やぶきた & 2.0 & 1.8 & 1.7 & 1.7 & 2.0 & 2.0 & 2.0 & 1.7 & 1.9 & やや強 \\
\hline かなやみどり & 1.0 & 1.6 & 1.0 & 1.0 & 1.3 & 1.0 & 1.3 & 1.3 & 1.2 & 強 \\
\hline ゆたかみどり & 2.0 & 2.9 & 2.7 & 3.7 & 3.0 & 2.7 & 3.0 & 3.0 & 2.9 & やや弱 \\
\hline
\end{tabular}

a 固場における自然発生程度：1 (無) 5 (多)

表11 系適試験地における而寒性 ${ }^{\mathrm{a}}$

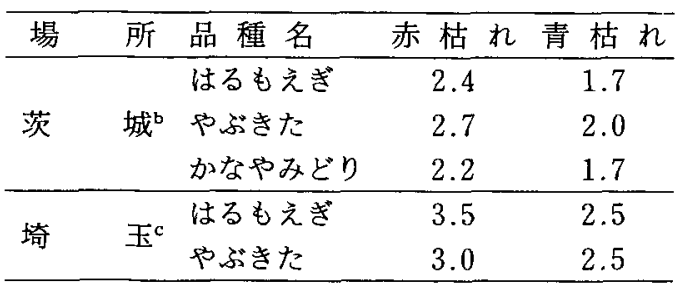

a 固場に扔ける自然発生程度：1 (無) 5(多)

$\mathrm{b}$ 赤枯れは 5 力年, 青枯れは 3 力年の平均値

c 赤枯れ，青枯れともに 2 力年の平均値

\section{表12 育成地における秋芽の伸青停止の早晚 ${ }^{\mathrm{a}}$}

\begin{tabular}{lcccc}
\hline 品種名 & 1988年 & 1989年 & 1990年 & 平 均 \\
\hline はるもえぎ & 3.0 & 2.5 & 2.0 & 2.5 \\
やぶきた & 3.0 & 3.0 & 3.0 & 3.0 \\
かなやみどり & 2.0 & 2.0 & 2.5 & 2.2 \\
\hline
\end{tabular}

$\mathrm{a}$ 秋芽の伸育停止：1 (早) 5 (晚)

$\dagger 2$ 宮崎県総合農業試験場茶業支場：チャ遺伝資源収集・保存並びに特性調査成績書,p 9 (2001) 
やや早いこともあって，11月における耐凍性の 確保がやぶきた’より早く,また, 12 月の耐凍性 も‘やぶきた’より強い(表12, 表13)。なお，鹿 児島県で行った特性検定試験裂傷型凍害抵抗性 は‘やぶきた’より強いやや強と評価された(表14)。

\section{5 而病虫性}

育成地における炭疽病抵抗性は中で, 通常の 条件下では防除の必要はないが，多発が予想さ れる場合には防除を必要とする（表15）。
輪斑病 (Pestalotiopsis longiseta) 分生胞子の付 傷接種により人為検定)を行った結果, ‘るるもえ ぎの成葉では発病率が低く，病斑も小さく，抵 抗性を強と評価した（表16）。

赫病については, 多発した1997年〜1998年 の発生程度がやぶきたよりやや多く、多発が予 想される場合には防除が必要である（表17）。

静岡県で実施された自然条件におけるもち病 抵抗性検定試験の結果, 抵抗性が弱のくらさわ’ より発病葉数が少ないものの,ややぶきた’と同程

表13 育成地における裂傷型凍害抵抗性 ${ }^{\mathrm{a}}$

\begin{tabular}{|c|c|c|c|c|c|c|c|c|c|}
\hline \multirow{2}{*}{ 品 } & \multirow{2}{*}{ 種 } & \multicolumn{2}{|c|}{ 1988年 } & \multirow{2}{*}{$\frac{1989 \text { 年 }}{\text { 11月下旬 }}$} & \multicolumn{2}{|c|}{ 1996年 } & \multicolumn{2}{|c|}{ 平均 } & \multirow{2}{*}{ 評 価 } \\
\hline & & 11月上旬 & 12月上旬 & & 11月下旬 & 12月上旬 & 11月 & 12月 & \\
\hline \multicolumn{2}{|c|}{ はるもえざ } & 2.7 & 1.6 & 1.4 & 2.1 & 1.7 & 2.1 & 1.7 & やや強 \\
\hline \multicolumn{2}{|c|}{ やぶきた } & 3.1 & 2.8 & 3.1 & 4.9 & 2.8 & 3.7 & 2.8 & やや弱 \\
\hline \multicolumn{2}{|c|}{ かなやみどり } & 2.5 & 2.4 & 2.8 & 4.3 & 1.5 & 3.2 & 2.0 & 中 \\
\hline \multicolumn{2}{|c|}{ のたかみどり } & 4.2 & 2.9 & 5.0 & 4.9 & 3.6 & 4.7 & 3.3 & 弱 \\
\hline
\end{tabular}

$\mathrm{a}$ 切り枝の低温処理による検定 $\left(11\right.$ 月 $-4 \sim-7^{\circ} \mathrm{C} 、 12$ 月 $-8 \sim 9^{\circ} \mathrm{C} 、$ 約16時間処理) 数值： 1 (強) 5 (弱)

\section{表14 裂傷型凍害抵抗性 ${ }^{\mathrm{a}}$ （鹿児島県茶業試験場）}

\begin{tabular}{|c|c|c|c|c|c|c|c|c|c|c|c|c|}
\hline \multirow{3}{*}{ 品 種 名 } & \multicolumn{11}{|c|}{ 人為低温処理による裂傷型凍害発生率（\%） } & \multirow{3}{*}{$\begin{array}{l}\text { 総 合 } \\
\text { 判 定 }\end{array}$} \\
\hline & \multirow{2}{*}{\multicolumn{2}{|c|}{$\begin{array}{l}\text { 1991年 1992年 } \\
\text { 11月下旬11日虫旬 }\end{array}$}} & 1993年 & \multicolumn{2}{|c|}{ 1994年 } & \multicolumn{2}{|c|}{ 1995年 } & \multicolumn{2}{|c|}{ 1996年 } & \multicolumn{2}{|c|}{ 平均 } & \\
\hline & & & 11月下旬 & 11 月上旬 & 11月下旬 & 11月上旬 & 11月下旬 & 11月上旬 & 11月下旬 & 11月上旬 & 11月中下旬 & \\
\hline \multirow[t]{2}{*}{ はるもえぎ } & 60.0 & 10.0 & 40.0 & 0.0 & 0.0 & 0.0 & 5.0 & 85.0 & 5.0 & 28.3 & 20.0 & やや強 \\
\hline & & & $(0.0)$ & & $(6.0)$ & & & & & & $(3.0)$ & \\
\hline \multirow[t]{2}{*}{ やぶきた } & 70.0 & 40.0 & 60.0 & 50.0 & 60.0 & 50.0 & 75.0 & 95.0 & 25.0 & 65.0 & 55.0 & 中 \\
\hline & & & $(0.0)$ & & $(8.2)$ & & & & & & (4.1) & \\
\hline \multirow[t]{2}{*}{ ゆたかみどり } & 70.0 & 90.0 & 53.0 & 80.0 & 70.0 & 45.0 & 50.0 & 60.0 & 50.0 & 61.7 & 63.0 & やや弱 \\
\hline & & & (6.3) & & $(4.2)$ & & & & & & (5.3) & \\
\hline \multirow[t]{2}{*}{ さやまかおり } & 40.0 & 10.0 & 58.0 & 10.0 & 30.0 & 0.0 & 50.0 & 100.0 & 15.0 & 36.7 & 33.8 & 強 \\
\hline & & & $(0.0)$ & & $(0.0)$ & & & & & & $(0.0)$ & \\
\hline \multirow[t]{2}{*}{ かなやみどり } & 20.0 & 10.0 & 0.0 & 20.0 & 30.0 & 35.0 & 20.0 & 100.0 & 15.0 & 51.7 & 15.8 & 強 \\
\hline & & & $(0.0)$ & & $(0.0)$ & & & & & & $(0.0)$ & \\
\hline
\end{tabular}

a 自然発生が1993,1994年にみられ，その発生率を( )内に表示

表15 青成地における炭瘨病発生程度 ${ }^{\mathrm{a}}$

\begin{tabular}{|c|c|c|c|c|c|c|c|c|}
\hline 品 種 名 & 1988年 & 1989年 & 1990年 & 1996年 & 1997年 & 1999年 & 平均 & 評価 \\
\hline はるもえぎ & 2.5 & 3.0 & 1.5 & 1.7 & 1.0 & 2.0 & 2.0 & 中 \\
\hline やぶきた & 3.0 & 4.3 & 2.0 & 2.0 & 1.7 & 3.7 & 2.8 & 弱 \\
\hline かなやみどり & 2.0 & 2.7 & 1.0 & 1.7 & 1.0 & 1.7 & 1.7 & 中 \\
\hline さやまかおり & 5.0 & 5.0 & 3.0 & 2.7 & 2.7 & 4.0 & 3.7 & 極弱 \\
\hline
\end{tabular}

a 自然条件下における発生程度：1 (無) 5 (多) 
度のやや弱と評価された（表18）。

クワシロカイガラムシについては, 多発年の 田場での自然発生程度がやぶきた’と同程度に多 かつた (表19)。また，卵数を指標とした検定 ${ }^{3)}$ 結果においてもややぶきた’同様に感受性と判断さ れる4ことから,発生には十分留意する必要があ る。

\section{6 製茶品質及び化学成分}

煎茶品質は, 育成地においては一番茶, 二番 茶とも‘やぶきた’よりやや優れた。項目別では， 特に色沢が優れ，香気は温和であり，滋味はま ろやかである(表20)。

系適試験における一番茶の製茶品質は, 合計 点がやぶきた’と同程度かそれ以上を示したとこ ろが 5 場所, やや劣ったところが 8 場所であり，

表16 青成地における輪玟病抵抗性 ${ }^{\mathrm{a}}$

\begin{tabular}{|c|c|c|c|c|c|c|c|c|}
\hline \multirow[b]{2}{*}{ 品 種 } & \multicolumn{2}{|c|}{ 1989年 } & \multicolumn{2}{|c|}{ 1996年 } & \multicolumn{3}{|c|}{ 平均 } & \multirow[b]{2}{*}{$\begin{array}{l}\text { 抵抗性 } \\
\text { 評 価 }\end{array}$} \\
\hline & $\begin{array}{c}\text { 発病率 } \\
(\%)\end{array}$ & $\begin{array}{c}\text { 病斑径 } \\
\text { (mm) }\end{array}$ & $\begin{array}{c}\text { 発病率 } \\
(\%)\end{array}$ & $\begin{array}{c}\text { 病斑径 } \\
(\mathrm{mm})\end{array}$ & $\begin{array}{c}\text { 発病率 } \\
(\%)\end{array}$ & $\begin{array}{c}\text { 病玨径 } \\
(\mathrm{mm})\end{array}$ & 評 価 ${ }^{b}$ & \\
\hline はるもえぎ & 26 & 4.2 & 65 & 5.3 & 46 & 4.8 & 1 & 強 \\
\hline やぶきた & 88 & 16.4 & 100 & 20.7 & 94 & 18.6 & (5) & 極 弱 \\
\hline かなゃみどり & 25 & 5.5 & 50 & 7.1 & 38 & 6.3 & 2 & やや強 \\
\hline
\end{tabular}

a 輪斑病分生胞子の付傷接種による検定結果

$\mathrm{b}$ 評価：1 (強) 5 (弱) (5)=極弱

表17 青成地における赤焼病発生程度 ${ }^{\mathrm{a}}$

\begin{tabular}{|c|c|c|c|}
\hline 品 種 名 & 1997年 & 1998年 & 平均 \\
\hline はるもえぎ & 2.7 & 4.7 & 3.7 \\
\hline やぶきた & 2.0 & 3.7 & 2.9 \\
\hline かなやみどり & 1.3 & 3.7 & 2.5 \\
\hline
\end{tabular}

a 固場における自然発生程度：1 (無) 5 (多)

\section{表18もち病抵抗性（静岡県茶業試験場）}

\begin{tabular}{lcccccccc}
\hline \multirow{2}{*}{ 品種 名 } & \multicolumn{7}{c}{ 発病葉数 ${ }^{\mathrm{a}}$ (枚) } & \multirow{2}{*}{ 平 価 } \\
\cline { 2 - 9 } & 1993 年 & 1994 年 & 1995 年 & 1996 年 & 1997 年 & 1998 年 & 1999 年 & \\
\hline はるもえぎ & 7.0 & 0.0 & 3.0 & 2.5 & 1.5 & 0.5 & 8.5 & やや弱 \\
やぶきた & 6.0 & 1.0 & 1.0 & 0.7 & 4.0 & 2.5 & 5.0 & やや弱 \\
くらさわ & 14.0 & 3.0 & 2.0 & 1.8 & 43.0 & 7.0 & 19.5 & 弱 \\
おくひかり & 1.5 & 0.0 & 0.0 & 1.0 & 0.0 & 0.0 & 1.0 & やや強 \\
\hline
\end{tabular}

a 山間地域における自然発生程度（定植 1 年目〜 7 年目）

1993年は全株(11本)，1994,1996,1999年は50cm ×50cm枠内，1995年は畦長 $1 \mathrm{~m}$,

1997年は畦長 $50 \mathrm{~cm}, 1998$ 年は $20 \mathrm{~cm} \times 40 \mathrm{~cm}$ 発病葉数

\section{表19 䏍成地におけるクワシロカイガラムシの発生程度 ${ }^{\mathrm{a}}$}

\begin{tabular}{|c|c|c|c|c|c|}
\hline 品 種 名 & 1997年 & 1998年 & 1999年 & 平 & 評 価 \\
\hline はるもえぎ & 2.7 & 3.7 & 5.0 & 3.8 & やや弱 \\
\hline やぶきた & 1.7 & 3.5 & 5.0 & 3.4 & やや弱 \\
\hline かなやみどり & 2.0 & 3.3 & 6.0 & 3.8 & やや弱 \\
\hline
\end{tabular}

a 固場における自然発生程度：1 (無) 5 (多)，6 (起) 


\section{表20 育成地における製茶品質}

\begin{tabular}{|c|c|c|c|c|c|c|c|c|c|c|c|c|}
\hline \multirow{2}{*}{ 品 種 名 } & \multicolumn{6}{|c|}{ 一番茶 } & \multicolumn{6}{|c|}{ 二番茶 } \\
\hline & 形状 & 色沢 & 香気 & 水色 & 滋味 & 合計 & 形状 & 色沢 & 香気 & 水色 & 滋味 & 合計 \\
\hline はるもえぎ & 8.6 & 9.5 & 7.9 & 7.5 & 7.6 & 41.1 & 8.0 & 8.6 & 6.8 & 7.4 & 6.7 & 37.4 \\
\hline やぶきた & 8.2 & 8.0 & 7.8 & 8.0 & 8.0 & 40.0 & 7.8 & 7.6 & 6.3 & 7.6 & 6.6 & 35.9 \\
\hline かなやみどり & 8.2 & 7.5 & 7.1 & 8.2 & 7.3 & 38.3 & 7.6 & 7.4 & 6.1 & 8.0 & 6.2 & 35.3 \\
\hline
\end{tabular}

a $50 \mathrm{~g}$ 機製茶サンプルの官能審査結果 (各項目10点満点)で，1988～1990年, 1996〜1999年の平均値 (二番茶は1988年を除く)

表21＼cjkstart系適試験における製茶品質 ${ }^{a}$

\begin{tabular}{|c|c|c|c|c|c|c|c|c|c|c|c|c|c|c|c|}
\hline \multirow{2}{*}{\multicolumn{2}{|c|}{ 場 所 品種名 }} & \multicolumn{7}{|c|}{ 一番茶 } & \multicolumn{7}{|c|}{ 二番茶 } \\
\hline & & & 形状 & 色沢 & 香気 & 水色 & 滋味 & 合訊 & & 形状 & 色沢 & 香気 & 水色 & 滋味 & 合計 \\
\hline \multirow{4}{*}{ 茨 城 } & はるもえぎ & \multirow{3}{*}{ (3) } & 9.0 & 9.0 & 8.7 & 8.3 & 9.2 & 44.2 & \multirow{3}{*}{ (2) } & 8.5 & 8.5 & 8.0 & 9.0 & 8.5 & 42.5 \\
\hline & やぶ & & 9.3 & 9.0 & 9.3 & 9.0 & 9.3 & 46.0 & & 8.5 & 9.0 & 9.0 & 7.5 & 7.0 & 41.0 \\
\hline & かなやみどり & & 7.7 & 8.3 & 8.0 & 8.0 & 8.0 & 40.0 & & 8.0 & 9.0 & 7.5 & 7.5 & 7.5 & 39.5 \\
\hline & はるもえぎ & \multirow{3}{*}{ (3) } & 8.2 & 8.8 & 9.7 & 8.7 & 8.7 & 44.0 & \multirow{3}{*}{ (3) } & 8.0 & 8.3 & 9.0 & 10.0 & 9.3 & 44.7 \\
\hline \multirow[t]{3}{*}{ 三重 } & やぶきた & & 8.7 & 9.2 & 8.3 & 9.3 & 9.0 & 44.5 & & 8.8 & 7.8 & 8.5 & 9.0 & 9.2 & 43.3 \\
\hline & かなやみどり & & 7.3 & 7.3 & 6.7 & 9.0 & 6.3 & 36.7 & & 8.7 & 8.8 & 8.3 & 7.2 & 7.2 & 40.2 \\
\hline & はるもえぎ & \multirow{3}{*}{ (4) } & 7.3 & 6.8 & 7.5 & 8.8 & 7.3 & 37.5 & \multirow{3}{*}{ (2) } & 10.0 & 10.0 & 9.0 & 10.0 & 10.0 & 49.0 \\
\hline \multirow[t]{3}{*}{ 宗 都 } & やぶ & & 8.3 & 8.3 & 8.0 & 8.0 & 7.0 & 39.5 & & 7.0 & 7.0 & 7.0 & 8.0 & 7.0 & 36.0 \\
\hline & かな & & 6.0 & 6.5 & 6.3 & 6.3 & 5.5 & 30.5 & & - & - & - & - & - & - \\
\hline & はるもえぎ & & 6.8 & 7.8 & 7.3 & 10.0 & 7.9 & 39.6 & \multirow{3}{*}{ (4) } & 7.5 & 8.0 & 8.9 & 9.4 & 8.4 & 42.1 \\
\hline \multirow[t]{3}{*}{ 高 知 } & やぶきた & \multirow[t]{2}{*}{ (4) } & 7.8 & 7.9 & 8.3 & 9.1 & 9.3 & 42.3 & & 8.0 & 8.0 & 9.0 & 9.4 & 8.0 & 42.4 \\
\hline & メどり & & 8.5 & 7.8 & 9.0 & 8.5 & 7.8 & 41.5 & & 9.3 & 8.5 & 7.3 & 9.4 & 7.8 & 42.1 \\
\hline & はるもえぎ & & 9.5 & 9.5 & 9.5 & 9.5 & 9.5 & 47.5 & & - & - & - & - & - & - \\
\hline 熊 本 & やぶきた & (2) & 9.5 & 8.5 & 10.0 & 9.5 & 10.0 & 47.5 & & - & - & - & - & - & - \\
\hline & 《どり & & 10.0 & 9.5 & 8.0 & 9.0 & 9.0 & 45.5 & & - & - & - & - & - & - \\
\hline & えぎ & & 7.3 & 8.2 & 8.1 & 7.6 & 7.9 & 39.0 & & - & - & - & - & - & 25.6 \\
\hline 静 岡 & やぶ & (4) & 7.9 & 8.1 & 8.0 & 8.0 & 8.4 & 40.4 & (3) & - & - & - & - & - & 24.0 \\
\hline & かな & & 8.0 & 8.0 & 8.1 & 7.9 & 8.4 & 40.4 & & - & - & - & - & - & 23.4 \\
\hline & はる & & 10.0 & 10.0 & 10.0 & 7.0 & 6.0 & 43.0 & & - & - & - & - & - & - \\
\hline 奈良 & ps & (1) & 8.0 & 9.0 & 5.0 & 7.0 & 7.0 & 36.0 & & - & - & - & - & - & - \\
\hline & かな & & 10.0 & 10.0 & 7.0 & 9.0 & 8.0 & 44.0 & & - & - & - & - & - & - \\
\hline & はる & & - & - & - & - & - & - & & 9.0 & 9.0 & 7.0 & 8.0 & 7.0 & 40.0 \\
\hline 岡 山 & やぶ & & - & - & - & - & - & - & (1) & 9.0 & 9.0 & 9.0 & 10.0 & 9.0 & 46.0 \\
\hline & かな & & - & - & - & - & - & - & & 8.0 & 7.0 & 8.0 & 9.0 & 10.0 & 42.0 \\
\hline & はる & & 7.0 & 8.3 & 8.8 & 8.3 & 8.2 & 40.7 & & 9.0 & 9.3 & 9.5 & 6.5 & 7.3 & 41.5 \\
\hline 昤者川 & やぶ & (3) & 8.3 & 7.7 & 7.8 & 8.0 & 7.7 & 39.5 & (2) & 8.8 & 7.5 & 8.0 & 9.5 & 9.5 & 43.3 \\
\hline & みどり & & 8.7 & 9.0 & 8.8 & 8.7 & 8.5 & 43.7 & & 8.0 & 7.5 & 6.5 & 7.5 & 7.8 & 37.3 \\
\hline & えぎ & & 8.5 & 9.0 & 9.0 & 9.5 & 8.5 & 44.5 & & 8.0 & 9.0 & 8.0 & 7.0 & 7.0 & 39.0 \\
\hline 福 岡 & & (2) & 8.8 & 9.0 & 10.0 & 9.5 & 10.0 & 47.3 & (1) & 9.0 & 8.0 & 9.0 & 9.0 & 9.0 & 44.0 \\
\hline & かな & & 9.0 & 8.5 & 8.0 & 8.5 & 7.5 & 41.5 & & 9.0 & 7.0 & 8.0 & 9.0 & 9.0 & 42.0 \\
\hline & はるもえぎ & & 5.7 & 6.5 & 8.5 & 8.2 & 8.5 & 37.3 & & 5.5 & 6.0 & 5.3 & 5.0 & 5.0 & 26.8 \\
\hline 佐 賀 & & (3) & 8. & 7.2 & 8. & 7.5 & 7.8 & 38.8 & (2) & 5.0 & 4.5 & 6.3 & 6.5 & 6.5 & 28.8 \\
\hline & & & 6 & 6.3 & 7.3 & 7.7 & 7.3 & 34.7 & & 5.3 & 5.0 & 5.3 & 6.0 & 5.3 & 26.8 \\
\hline & はるもえぎ & & 4.8 & 5.0 & 5.7 & 6.7 & 5.3 & 27.5 & & - & - & - & - & - & - \\
\hline 大分 & & (3) & 5.3 & 5.5 & 5. & 6.0 & 6.0 & 28.7 & & - & - & - & - & - & - \\
\hline & & & & 5 & 5. & 6 & 5.5 & 28.5 & & - & - & - & - & - & - \\
\hline & はるも & & 8.7 & 9.3 & 7.6 & 7.5 & 7.5 & 40.5 & & 8.0 & 8.5 & 6.6 & 7.5 & & 37.3 \\
\hline 宮 崎 & やぶき & (4) & 8.0 & 8.3 & 7.7 & 8.0 & 7.6 & 39.6 & (4) & 7.5 & 8.1 & 6.2 & 7.5 & 6.3 & 35.5 \\
\hline & & & 8.1 & 7.3 & 6.8 & 7.9 & 6.7 & 36.7 & & 7.5 & 7.3 & 5.9 & 8.1 & 6.0 & 34.8 \\
\hline & はるもえぎ & & 9.3 & 10.0 & 9.8 & 8.5 & 9.2 & 46.7 & & 9.4 & 10.0 & 10.0 & 9.9 & 9.7 & 49.0 \\
\hline 鹿児島 & やぶきた & (3) & 9.0 & 9.2 & 9.1 & 9.4 & 9.3 & 45.9 & (2) & 7.5 & 7.5 & 8.3 & 9.9 & 9.4 & 42.6 \\
\hline & かなやみどり & & 9.4 & 7.9 & 7.8 & 8.6 & 8.2 & 41.9 & & 8.3 & 7.9 & 8.5 & 9.0 & 8.2 & 41.8 \\
\hline
\end{tabular}

$\mathrm{a}$ 各項目 10 点満点（20点満点の場所は10点満点に換算）で，(1)〜(4)はそれぞれ試験年数を示す。 
(茶研報96:15～26, 2003)

表22 系適試験における荒茶の化学成分含有率 ${ }^{\mathrm{a}}$

\begin{tabular}{|c|c|c|c|c|c|c|c|c|c|c|c|c|c|}
\hline \multirow{2}{*}{ 場 所 } & \multirow{2}{*}{ 品 種 名 } & \multicolumn{6}{|c|}{ 一番茶 $(\%)$} & \multicolumn{6}{|c|}{ 二番茶 $(\%)$} \\
\hline & & \multicolumn{6}{|c|}{ 全窒索アミノ酸テアニン粗繊維 カフェインタンニン } & \multicolumn{6}{|c|}{ 全窑素アミノ酸テアニン粗織維カフェインタンニン } \\
\hline \multirow{3}{*}{ 佐 賀 } & はるもえぎ & 6.5 & 4.9 & 2.7 & 17.4 & - & 10.9 & 4.4 & 2.0 & - & - & - & 15.5 \\
\hline & やぶきた & 6.1 & 4.2 & 2.3 & 15.9 & - & 14.1 & 4.5 & 1.9 & - & - & - & 16.9 \\
\hline & おくみどり & 5.5 & 3.2 & 1.7 & 18.0 & - & 15.6 & 4.0 & 1.4 & - & - & - & 16.4 \\
\hline \multirow{3}{*}{ 宮 崎 } & はるもえぎ & 6.4 & 4.5 & 2.7 & 16.5 & 3.5 & 11.6 & 5.7 & 2.9 & 1.9 & 18.1 & 3.4 & 14.0 \\
\hline & やぶきた & 6.0 & 3.8 & 2.2 & 17.1 & 3.1 & 13.3 & 5.3 & 2.4 & 1.4 & 19.1 & 3.1 & 16.5 \\
\hline & かなやみどり & 5.5 & 2.7 & 1.4 & 17.3 & 3.5 & 17.0 & 4.9 & 1.8 & 0.9 & 19.8 & 3.2 & $17.9^{\circ}$ \\
\hline \multirow{3}{*}{ 鹿児島 } & はるもえぎ & 6.3 & 4.8 & 2.7 & 17.4 & 2.8 & 10.8 & - & - & - & - & - & - \\
\hline & やぶきた & 6.1 & 4.3 & 2.3 & 17.1 & 2.7 & 12.5 & - & - & - & - & - & - \\
\hline & かなやみどり & 5.5 & 3.3 & 1.7 & 18.1 & 3.0 & 14.8 & - & - & - & - & - & - \\
\hline
\end{tabular}

a 成分は近赤外分光分析計による分析値で，佐賀は1992,1999年，宮崎は1996〜1999年，鹿児島は 1998〜1999年の平均值

二番茶においてはそれぞれ 6 場所及び 5 場所で あった。地域別では, 南九州における評価が特 に高かった（表21）。

荒茶の化学成分は, ‘ぶきた’に比べ，うま味 成分であるアミノ酸含有率が高く，啮味成分で あるタンニン含有率は低い（表22）。

\section{4 適地及び栽培上の注意}

耐寒性は, 赤枯れ抵抗性, 裂傷型凍害抵抗性と もやや強であり, 全国の茶産地で栽培可能である が, 系適試験に扔ける収量, 品質面からみると暖 地での栽培が適しており,ややぶきた”とかなやみ どり’間に摘採できる品種として利用できる。

樹姿が直立型で, 株張りがやや小さいので複 条植えにして株張りを確保する必要がある。

耐病性では，もち病及び赤焼病には弱いので 発生には注意が必要である。また, 炭疽病につ いては,通常の条件下では防除の必要はないが, 多発が予想される場合には防除が必要である。

\section{5 命名の由来}

“はるもえぎ'(春萌黄)は，摘採期の新葉が淡 い緑色で, 夏茶も赤みを帯びず, 製品の色沢も 鮮緑色であることに由来する。

\section{6 摘 要}

“はるもえぎは, 1981年に宮崎県総合農業試験 場茶業支場に扝いで茶本F $F_{1}$ NN27’を種子親,
'ME52'を交配親として交配した中から選抜した 品種である。

1991年から1999年まで宮崎18号’の系統名で 17場所で系適試験，2場所で特性検定試験（も ち病, 裂傷型凍害) が実施された。

その結果, ‘やぶきた’とかかなやみどり’の間に 摘採できる品種として普及に移し得ると判断さ れ, 2003年 9 月に茶農林51号“はるもえぎ’として 農林登録された。

‘はるもえぎの特性の概要は次のとおりである。

1）一番茶の萌芽期,摘採期は‘やぶきた’より 2 日程度遅い中生品種である。

2 ）樹姿は直立型, 樹勢はやや強, 株張りは‘や ぶきた’よりやや小さい。摘採期の新葉は淡 緑である。

3 ）而病性は, 炭疽病には中, 輪斑病には強で ‘やぶきた’より強い。

4 ）耐寒性は, 赤枯れ, 裂傷型凍害ともやや強 である。

5 ）収量は‘やぶきた’と同程度である。

6）煎茶品質は良好で, 香気は温和で, 滋味は まろやかである。特に色沢が優れる。荒茶 に含まれる成分は, ‘やぶきた’に比べアミ， 酸含有率が高く,タンニン含有率は低い。 


\section{7 引用文献}

1) 古野鶴吉 (1998)：チャ遺伝資源の裂傷型凍 害抵抗性の特性評価. 茶研報, №.86, 37-42.

2 ) 古野鶴吉 (1996)：チャ遺伝資源の輪斑病抵 抗性の特性評価。茶研報, NNo.83,41-46.
3 ）水田隆史(2003)：チャ樹におけるクワシロ カイガラムシの発育と増殖の品種間差異. 応動昆, 47,41-46.

4 ）佐藤邦彦・水田隆史 (2003)：チャのクワシ ロカイガラムシ抵抗性品種の利用と物理的 防除の可能性. 今月の農業， $11,43 \sim 46$.

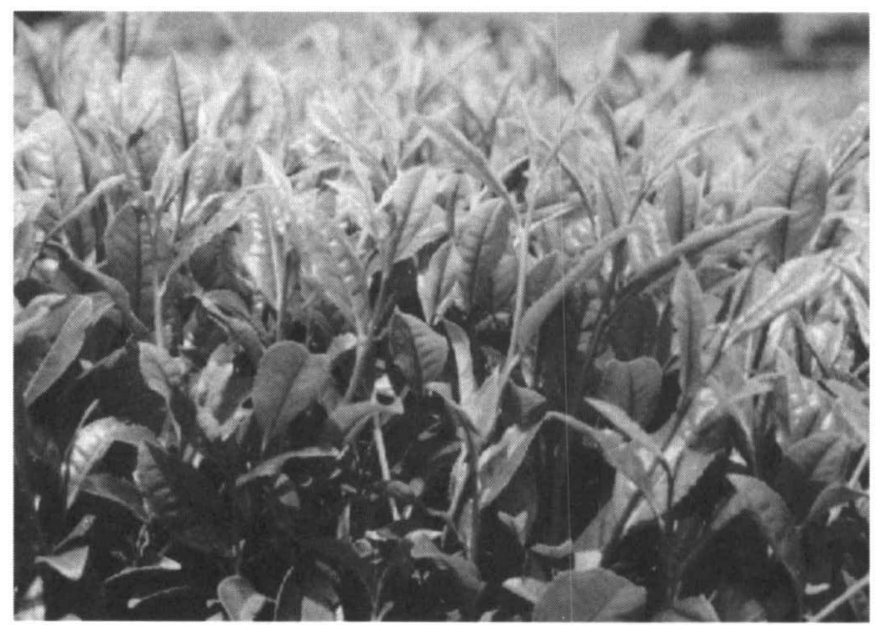

写真 1 ‘はるもえぎの一番茶摘採期の新芽

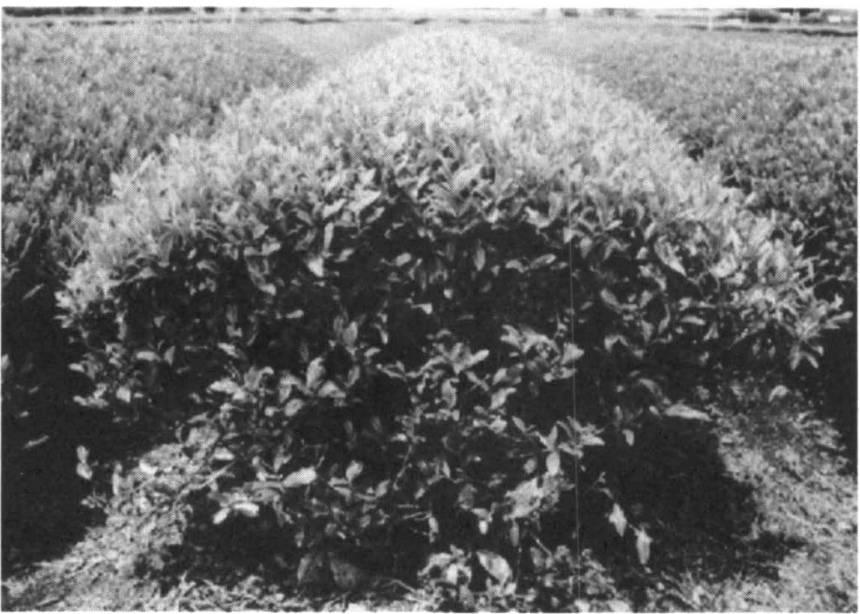

写真 2 ‘はるもえぎの一番茶摘採期の園相 